\title{
Phytochemical analysis, Anti inflammatory activity, in vitro antidiabetic activity and GC-MS profile of Erythrina variegata L. bark
}

\author{
Nagaraj Santhiya, Suriyamoorthy Priyanga, Subrhamanian Hemmalakshmi, Kanakasabapathi Devaki* \\ Department of Biochemistry, Karpagam University, Coimbatore-641 021, India.
}

\begin{tabular}{l} 
ARTICLE INFO \\
\hline Article history: \\
Received on: 07/03/2016 \\
Revised on: 04/04/2016 \\
Accepted on: 22/04/2016 \\
Available online: $28 / 07 / 2016$ \\
\hline Key words: \\
E. variegata, \\
Phytoconstituents, DPPH, \\
Glycosylation of \\
hemoglobin, GC-MS.
\end{tabular}

\begin{abstract}
Many beneficial medicinal products are used to treat various serious diseases and disorders like diabetes, cancer and cardiovascular diseases without side effects. Hence our study focused to investigate the phytochemical analysis, quantification of bioactive compounds (alkaloid, phenols, flavonoids), in vitro free radical scavenging activity, anti-inflammatory activity (Membrane stabilization assay), in vitro anti-diabetic activity by enzyme inhibition activity, glucose uptake assay in isolated rat hemi-diaphragm and in yeast cells and also record GCMS profile of Erythrina variegata L. bark (methanolic extract) which has boundless medicinal properties. The results of this study showed the evidence that the extracts when tested for their phytochemicals and free radical scavenging activity were found to have considerable antioxidant potential. This plant also exhibit better in vitro enzyme inhibitory activity, inhibition of non- enzymatic glycosylation of hemoglobin, in vitro anti-diabetic activity proved by glucose uptake assays and anti-inflammatory activity. GC-MS analysis of methanolic extract of Erythrina variegata L. bark revealed the presence of 58 compounds which are responsible for pharmacological activities. The results of this study indicate that the methanolic extract of Erythrina variegata L. bark has significant pharmacological properties.
\end{abstract}

\section{INTRODUCTION}

Medicinal plants are the bio resources given by natural world used to heal a group of human diseases to evaluate their probable sources for new drugs (Priyanga et al., 2014). Plant parts have been a typical source of medicine from an ancient time and have been the primary source of drugs in Indian systems of medicine and other ancient systems in the world (Devi et al., 2011). Phytochemicals are the natural bioactive compounds present in plants and the most substantial bioactive constituents of plants are alkaloids, tannins, flavonoids, steroids, terpenoids, carbohydrates and phenolic compounds (Priyanga et al., 2014; Sowmya et al., 2015). Inflammation is a serious problem and the commonly used drug for managing of inflammatory conditions are non-steroidal anti-inflammatory drugs, which have several adverse effects especially gastric irritation leading to the formation of gastric ulcers (Sangita et al., 2012).

* Corresponding Author

Dr. K. Devaki, Department of Biochemistry, Karpagam University, Coimbatore 641 021, India. Telephone number: 091-0422-6453777, Fax : 091-0422-2980022,E-mail:dr.devaki.bc@gmail.com
Diabetes mellitus is a chronic endocrine disorder that disrupts the metabolism of carbohydrates, proteins, fat, electrolytes and water. It includes a group of metabolic diseases categorized by hyperglycemia, in which blood sugar levels are elevated either because the pancreas do not synthesize enough insulin or cells do not respond to the produced insulin (West, 2000; Sangeetha et al., 2015).

According to WHO, it is estimated that $3 \%$ of the world's population have diabetes and the prevalence is expected to double by the year 2025 (Megha et al., 2013). Nearly 400 traditional plants have been stated for the treatment of diabetes (Upwar et al., 2011).

Plant food rich in polyphenols have been reported to cause effects similar to insulin in the utilization of glucose and act as good inhibitors of crucial enzymes like alpha amylase and alpha glucosidase associated with type 2 diabetes and lipid peroxidation in tissues (Reddy et al., 2010). Crude extract acquired from the $E$. variegata was evaluated for its radical scavenging properties and assessed that it could be a rich source of natural oxidants with potential applications (Anwar, 2006). 
Various parts of this plant is used in alternative system of medicine for wind damp obstruction syndrome, rheumatic joint problems, lower back, knee pain, asthma, nerve depression, epilepsy and insect bites (Devaki et al., 2015).

Different parts of $E$. variegata have used in traditional medicine as nervine sedative, febrifuge, anti-asthmatic and antiepileptic and also it has potential effects for treatment of some diseases like convulsion, fever, inflammation, bacterial infection, insomnia, helminthiasis, cough, cuts and wounds (Kumar et al., 2010).

The plant bark is astringent, febrifuge, anti-bilious, anthelmintic, and it is too useful in opthalmia and skin diseases. The leaves are used in fever, inflammation and joint pain and the juice of the leaves are used to relieve earache and toothache. The roots are used in bronchitis, febrifuge and as an insecticide. The roots are also used in the treatment of cancer, convulsions and used to treat pimples. It has the repute to stimulate lactation and menstruation and is used as laxative, diuretic and expectorant (Baskar et al., 2010). The present study was focused to evaluate the phytochemical analysis, anti-inflammatory activity, in vitro antidiabetic activity and to record the GC-MS profile of Erythrina variegata $\mathrm{L}$. bark (methanolic extract).

\section{MATERIALS AND METHODS}

\section{Plant material}

The plant material for the proposed study was collected from Kodaikannal, Dindigul district, Tamil Nadu, India. The plant was authenticated by Dr. G.V.S. Moorthy, Botanical Survey of India, TNAU campus Coimbatore, with the voucher number BSI/SRC/5/23/2013-14/Tech/1500.

\section{Preparation of Methanol extract}

$50 \mathrm{~g}$ of powdered plant material (Bark) was weighed and extracted with $250 \mathrm{ml}$ of methanol for 72 hours using occasional shaker. The supernatant was collected and concentrated at $40^{\circ} \mathrm{C}$. It was stored at $4^{\circ} \mathrm{C}$ in an air tight bottle for further studies.

\section{Preparation of animals}

Albino Wistar male rats, weighing 100-150g were obtained from the institutional animal house of Karpagam Academy of Higher Education, Coimbatore and were used for the study. The animals were housed at a room temperature of $25 \pm 2{ }^{\circ} \mathrm{C}$, relative humidity of $75 \pm 5 \%$ and $12 \mathrm{hrs}$ dark-light cycle; animals were fed with standard laboratory diet and water ad libitum. The study was approved by IAEC and the experiments were conducted according to the ethical norms and Institutional Animal Ethics Committee Guidelines.

\section{Phytochemical analysis}

The qualitative analysis of secondary metabolites was carried out by following the methods of Trease and Evans (1996) and Harborne (1987).

\section{Quantification of bioactive compounds}

The bioactive compounds alkaloid, phenols and flavonoids were quantified according to the standard procedure. The total alkaloid present in the methanolic extract of Erythrina variegata L. bark was determined by the modified method of Harborne (1973). The total phenols present in the sample were estimated by (Singleton and Rossi, 1965) and the total flavonoid content by (Ordon et al., 2006).

\section{In vitro free radical scavenging activity}

The free radical scavenging activity of methanolic extract of Erythrina variegata L. bark were confirmed by reducing power activity by the method (Oyaizu, 1986) and the DPPH radical scavenging activity by the method (Blois, 1958).

\section{In vitro anti -diabetic assays $\alpha$-Amylase inhibitory activity}

The $\alpha$-amylase inhibitory activity was determined according to the method described by (Jyothi et al., 2011). Briefly, the total assay mixture containing $200 \mu \mathrm{l}$ of $0.02 \mathrm{M}$ sodium phosphate buffer, $20 \mu \mathrm{l}$ of enzyme and the plant extracts in the concentration range $10-100 \mu \mathrm{g} / \mathrm{ml}$ were incubated for $10 \mathrm{~min}$ at room temperature followed by the addition of $200 \mu \mathrm{l}$ of $1 \%$ starch in all the test tubes. The reaction was terminated with addition of $400 \mu \mathrm{l}$ of 3, 5 Dinitro salicylic acid (DNSA) color reagent tubes were placed in boiling water bath for 5 minutes, cooled at room temperature and diluted with $15 \mathrm{ml}$ of distilled water and the absorbance was measured at 540nm. The control samples were also prepared accordingly without any plant extracts and were compared with the test samples containing various concentrations of the plant extracts prepared with DMSO. The results were expressed as \% inhibition calculated using the formula:

Inhibition activity $(\%)=\frac{\mathrm{Abs}(\text { control })-\mathrm{Abs}(\text { extract })}{\mathrm{Abs}(\text { control })} \times 100$

\section{In vitro inhibitory assay for the $\alpha$-glucosidase activity}

The extract $(50 \mu \mathrm{L})$ and $100 \mu \mathrm{L}$ of $\alpha$-glucosidase solution $(1.0 \mathrm{U} / \mathrm{mL})$ in $0.1 \mathrm{M}$ phosphate buffer $(\mathrm{pH} 6.9)$ was incubated at $25^{\circ} \mathrm{C}$ for $10 \mathrm{~min}$. Then, $50 \mu \mathrm{L}$ of $5 \mathrm{mM}$ p-nitrophenyl- $\alpha$-D-gluco pyranoside solution in $0.1 \mathrm{M}$ phosphate buffer ( $\mathrm{pH}$ 6.9) was added. The mixtures were incubated at $25^{\circ} \mathrm{C}$ for $5 \mathrm{~min}$ before reading the absorbance at $405 \mathrm{~nm}$ in the spectrophotometer (Apostolidis et al., 2007). The $\alpha$ - glucosidase inhibitory activity was expressed as percentage inhibition. The $\mathrm{IC}_{50}$ of the extract was calculated.

Inhibition activity $(\%)=\frac{\mathrm{Abs}(\text { control })-\mathrm{Abs}(\text { extract })}{\mathrm{Abs}(\text { control })} \times 100$

\section{In vitro glucose uptake by isolated rat hemi-diaphragm}

Glucose uptake by rat hemi-diaphragm was estimated by the modified method described by (Walaas and Walaas, 1952; Chattopadhyay et al., 1992). Albino rats of either sex weighing between 160-180g were selected and maintained as described 
above. The animals were sacrificed by decapitation and diaphragm was dissected out quickly with minimal trauma and divided into two halves. The hemi-diaphragm was then rinsed in cold Tyrode solution (without glucose) to remove any blood clots and was placed in small culture tubes containing $2 \mathrm{ml}$ Tyrode solution with $2 \%$ glucose was incubated for 30 minutes at $37^{\circ} \mathrm{C}$ in an atmosphere of $100 \% \mathrm{O}_{2}$ with shaking. Four sets containing five numbers of graduated test tubes were treated as follows:

Group I: Served as control which contain $2 \mathrm{ml}$ Tyrode solution with $2 \%$ glucose and $2.0 \mathrm{ml}$ of distilled water.

Group II: Contain $2 \mathrm{ml}$ Tyrode solution with $2 \%$ glucose, regular insulin (Biocon) $0.62 \mathrm{ml}$ of 0.4 units per $\mathrm{ml}$ solution and $1.38 \mathrm{ml}$ of distilled water.

Group III: Contain $2 \mathrm{ml}$ Tyrode solution with $2 \%$ glucose, $0.6 \mathrm{ml}$ of E. variegata $(200 \mu \mathrm{g} / \mathrm{ml})$ and $1.4 \mathrm{ml}$ of distilled water.

Group IV: Contain $2 \mathrm{ml}$ Tyrode solution with $2 \%$ glucose, $0.6 \mathrm{ml}$ of $E$. variegata $(200 \mu \mathrm{g} / \mathrm{ml}), 0.62 \mathrm{ml}$ of 0.4 units per $\mathrm{ml}$ solution of Insulin and $0.78 \mathrm{ml}$ of distilled water.

Following incubation, the hemi-diaphragms were taken out and weighed. The glucose content of the incubated medium was measured by GOD-POD method. Glucose uptake per gram of tissue was the difference between the initial and final glucose content in the incubated medium. The uptake of glucose was expressed as $\mathrm{mg} / \mathrm{g}$ of moist tissue/30 min.

\section{Glucose uptake in Yeast cells}

Yeast cells were prepared according to the method of (Dinesh et al., 2009), briefly, commercial baker's yeast was washed by repeated centrifugation $(3,000 \times \mathrm{g} ; 5 \mathrm{~min})$ in distilled water until the supernatant fluids were clear and a $10 \%(\mathrm{v} / \mathrm{v})$ suspension was prepared in distilled water. Various concentrations of extracts $(1-5 \mathrm{mg})$ were added to $1 \mathrm{~mL}$ of glucose solution $(5,10$ and $25 \mathrm{mM}$ ) and incubated together for $10 \mathrm{~min}$ at $37^{\circ} \mathrm{C}$. Reaction was started by adding $100 \mu \mathrm{l}$ of yeast suspension, vortexed and further incubated at $37^{\circ} \mathrm{C}$ for $60 \mathrm{~min}$.

After $60 \mathrm{~min}$, the tubes were centrifuged $(2,500 \times \mathrm{g}, 5$ $\mathrm{min}$ ) and glucose was estimated in the supernatant. Metformin was taken as standard drug. The percentage increase in glucose uptake by yeast cells was calculated. All the tests were performed in triplicates.

\section{Non-enzymatic glycosylation of haemoglobin assay}

Antidiabetic activity of Erythrina variegata L. bark was investigated by estimating degree of non-enzymatic haemoglobin glycosylation, by colorimetrically at $520 \mathrm{~nm}$. Glucose $(2 \%)$, haemoglobin $(0.06 \%)$ and sodium azide $(0.02 \%)$ solutions were prepared in phosphate buffer $(0.01 \mathrm{M},) \mathrm{pH} 7.4 .1 \mathrm{ml}$ each of above solution was mixed and $1 \mathrm{ml}$ of each concentrations of plant sample were added to the mixture. The mixture was incubated in dark at room temperature for $72 \mathrm{hrs}$. The degree of glycosylation of haemoglobin was measured colorimetrically at $520 \mathrm{~nm}$. Alpha-
Tocopherol (Trolax) was used as a standard drug and \% inhibition was calculated (Megha et al., 2013; Gupta et al., 2013). All the tests were performed in triplicate.

\section{Membrane stabilization assay}

Blood was collected freshly and mixed with equal volume of Alsever's solution. It was then centrifuged at $3000 \mathrm{~g}$ for 15 minutes. The cells were washed with isosaline and a $10 \%$ suspension was made with isosaline. Different concentrations of methanolic extract $(100-500 \mu \mathrm{g} / \mathrm{ml})$ were prepared in isosaline. To $0.5 \mathrm{~mL}$ of the extract, $1 \mathrm{~mL}$ phosphate buffer, $2 \mathrm{~mL}$ hyposaline and $0.5 \mathrm{~mL}$ HRBC suspension was added and incubated for 30 minutes at $37^{\circ} \mathrm{C}$ and then centrifuged at $2500 \mathrm{rpm}$ for 20 minutes (Patel et al., 2012).

Absorbance was measured at $560 \mathrm{~nm}$. Aspirin was used as the standard and control was taken without the extract.

\section{Gas Chromatography - Mass Spectroscopy (GC-MS) analysis of the methanolic extract of Erythrina variegata L.bark}

GC-MS analysis of the methanolic extract of Erythrina variegata $\mathrm{L}$. bark was performed using the equipment Thermo GC-Trace Ultra Version: 5.0, Thermo MS DSQ II. The equipment has a DB 35 - MS Capillary Standard Non-polar column with dimensions of $30 \mathrm{mts}$ x $0.25 \mathrm{~mm}$ ID x 0.25 $\mu \mathrm{m}$ Film.

The carrier gas used is Helium at flow of $1.0 \mathrm{ml} /$ minute. The injector was operated at $250^{\circ} \mathrm{C}$ and the oven temperature was programmed as follows; $60^{\circ} \mathrm{C}$ for 15 minutes, then gradually increased to $280^{\circ} \mathrm{C}$ for 3 minutes. The identification of components was based on comparison of their mass spectra with those of Wiley and NBS libraries as well as comparison of their retention indices. The constituents were identified after comparison with those available in the computer library (NIST) attached to the GC-MS instrument and the results obtained have been tabulated.

\section{Statistical analysis}

All the experimental results were entered using three parallel measurements of the Mean \pm Standard deviation $(n=3)$.

\section{RESULTS AND DISCUSSION}

Various herbs and species are used in Indian cooking such as onion, Garlic, Ginger, Turmeric, Cardamom, Coriander etc has many medicinal properties (Vijayameena et al., 2013). Among this category one of the significant medicinal plant which show countless medicinal properties is Erythrina variegata Linn. The antibacterial and anti-inflammatory properties of Erythrina variegata Linn were documented in Chinese herbal medicine for the treatment of pyrexia, scabies and septicaemia (Baskar et al., 2010). 


\section{Phytochemical screening and Quantification of bioactive compounds}

The phytochemical screening of the methanolic extract of Erythrina variegata bark were carried and the results are given in the Table 1. The methanolic extract of Erythrina variegata shows the presence of major phytoconstituents like alkaloids, flavonoids, steroids, terpenoids, saponins, tannins, phenols and glycosides.

Herbal extracts hold diverse phytochemicals with biological activity that can be of valuable therapeutic index. The protective effect of fruits and vegetables has been qualified by phytochemicals, which are the non-nutrient plant compounds (Devi et al., 2011).

Table 1: Phytochemical constituents of Erythrina variegata L.

\begin{tabular}{lc}
\hline Phytochemical constituents & Solvent (methanol) \\
\hline Alkaloids & + \\
Steroids & + \\
Flavonoids & + \\
Tannins/phenols & + \\
Aminoacids and Proteins & + \\
Sugars & + \\
Glycosides & + \\
Saponins & + \\
Terpenoids & + \\
\hline
\end{tabular}

The Erythrina variegata L. bark methanolic extract contains alkaloids, phenols, flavonoids, tannins, steroids, terpenoids, glycosides and saponins as their secondary metabolites which is responsible for their pharmacological actions.

The total alkaloid content present in methanolic extract of Erythrina variegata L. bark was found to be $220 \pm 0.56 \mathrm{mg} / \mathrm{g}$. The total flavonoid content present in Erythrina variegata L. bark was found to be $200 \mathrm{mg} / \mathrm{g} \pm 0.72$. The total phenol content present in methanolic extract of Erythrina variegata L. bark methanolic extract was found to be $130 \mathrm{mg} / \mathrm{g} \pm 0.62$ (T able -2 ).

Phytochemicals play a vital role in plant defense against prey, microorganisms, stress as well as interspecies protections, these plant components have been used as drugs for eras. Hence, phytochemical screening serves as the first early step in predicting the kinds of potential active compounds from plants (Chew et al., 2011).

Table 2: Quantitative estimation of phytochemicals.

\begin{tabular}{ccc}
\hline S. No & Parameters & Content $(\mathbf{m g} / \mathbf{g})$ \\
\hline 1. & Alkaloid & $220 \pm 0.56$ \\
2. & Flavanoid & $200 \pm 0.72$ \\
3. & Phenol & $130 \pm 0.62$ \\
\hline
\end{tabular}

\section{In vitro free radical scavenging activity}

In DPPH assay different concentrations of extracts were used $(100-500 \mu \mathrm{g} / \mathrm{ml})$. The percent inhibition of the Erythrina variegata $\mathrm{L}$. bark methanolic extract was found to be increased in dose dependent manner, and the graph showing the results were given below. In Figure1, methanolic bark extract of Erythrina variegata showed maximum activity of $60.71 \%$ at $500 \mu \mathrm{g} / \mathrm{ml}$ whereas ascorbic acid at the same concentration exhibited $67.85 \%$ inhibition respectively. $\mathrm{IC}_{50}$ values were found to be $400 \pm 1.05$ $\mu \mathrm{g} / \mathrm{ml}$ and $300 \pm 0.76 \mu \mathrm{g} / \mathrm{ml}$ for the extract and the reference standard, ascorbic acid respectively.

DPPH radical scavenging test is worked on the principle, interchange of hydrogen atoms between the antioxidant and the constant DPPH free radical. DPPH is a stable free radical at room temperature which receives an electron or hydrogen radical to form a steady diamagnetic molecule. DPPH radical is condensed to the corresponding hydrazine, a colour change from violet to yellow in solution indicates the scavenging behavior of the crude plant sample due to bioactive compounds such as phenolic compounds, flavonoids, terpenoids and their derivatives (Priyanga et al., 2015).

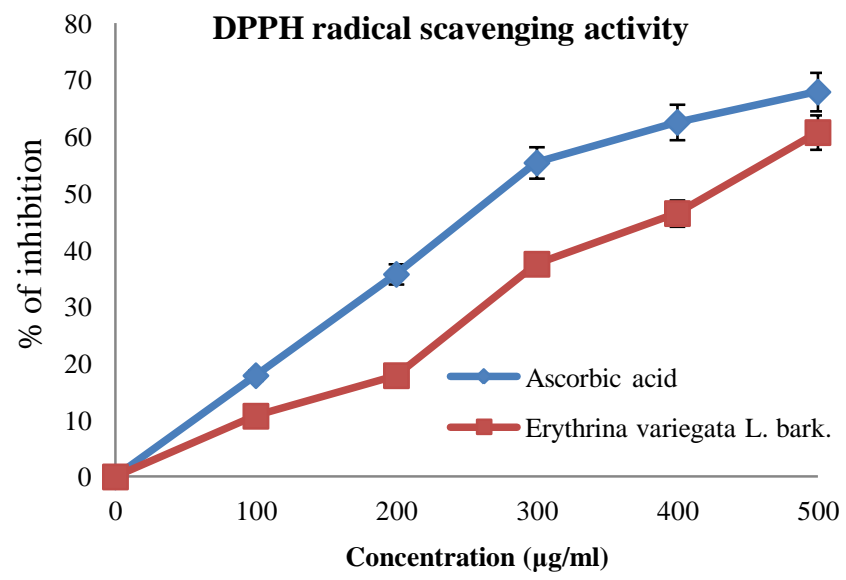

Fig. 1: DPPH radical scavenging activity of E. variegata L. bark extract. The values are expressed as Mean \pm SD of triplicates

The reducing capacity of a compound may serve as an important indicator of its potential antioxidant activity. Standard curves of ascorbic acid as well as the methanolic extract of Erythrina variegata L. bark are shown in Figure 2.

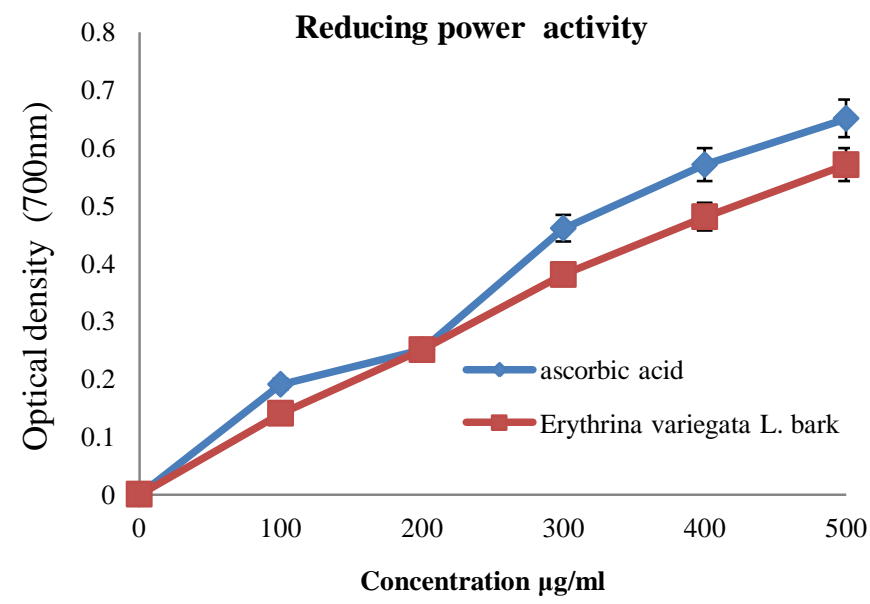

Fig. 2: Reducing power activity of E. variegata L. bark extract. The values are expressed as Mean \pm SD of triplicates

The Erythrina variegata L. bark methanolic extract antioxidant capability increases with the increasing concentration $(100-500 \mu \mathrm{g} / \mathrm{ml})$ like the antioxidant activity of standard curve. 
In vitro antidiabetic assays

In vitro glucose uptake assay by isolated rat hemi-diaphragm (Erythrina variegata L. bark methanolic extract)

The estimation of glucose content in rat hemi-diaphragm is a usually employed and reliable method for in vitro study of peripheral uptake of glucose. Antihyperglycemic behaviors of most efficient plants were in part explicated by the ability of the phytoconstituents to increase glucose transport and metabolism in muscle and to stimulate insulin secretion (McCue et al., 2004). Glucose uptake assay by isolated rat hemi-diaphragm (Erythrina variegata L. bark methanolic extract) were done using the extract concentration of $200 \mu \mathrm{g} / \mathrm{ml}$ and the activity were shown below.

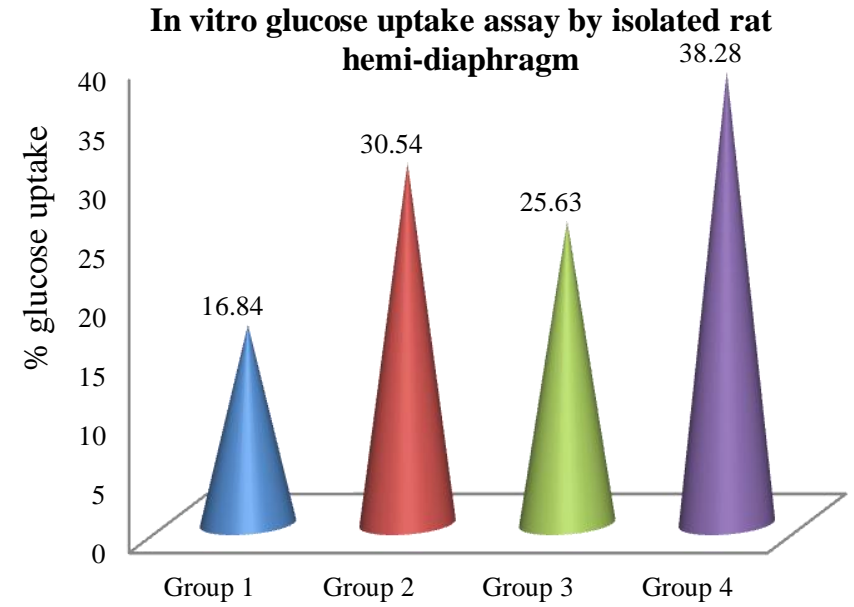

Fig. 3: In vitro glucose uptake assay by isolated rat hemi-diaphragm of $E$. variegata $\mathrm{L}$. bark extract

Values are expressed as Mean \pm SD of triplicates

Among the 4 groups, Glucose uptake were increased when treated with insulin alone compared to that of bark extract, and the bark extract were somewhat nearer to that of insulin, but when combine both the extract and insulin, glucose uptake by diaphragm were increased more and this indicates that insulin has some synergistic effect with the extract in uptake of glucose.

\section{Glucose uptake by Yeast cells}

The rate of glucose transport across cell membrane in yeast cells system was identified and the results are given below. The amount of glucose lingering in the medium later a specific time serves as a marker of the glucose uptake by the yeast cells (Wagner and Bladt, 2004).

In the diabetic patients, regulation of glucose level in the blood can prevent the various complications associated with the disease. The maintenance of plasma glucose concentration for a long term under a selection of dietary conditions is one of the most significant and closely regulated processes observed in the mammalian species (Megha et al., 2013)

E. variegata L. bark methanolic extract increased the glucose uptake in yeast cells. It increases with increasing concentration and the results are comparable with that of the standard which was shown in figure 4.

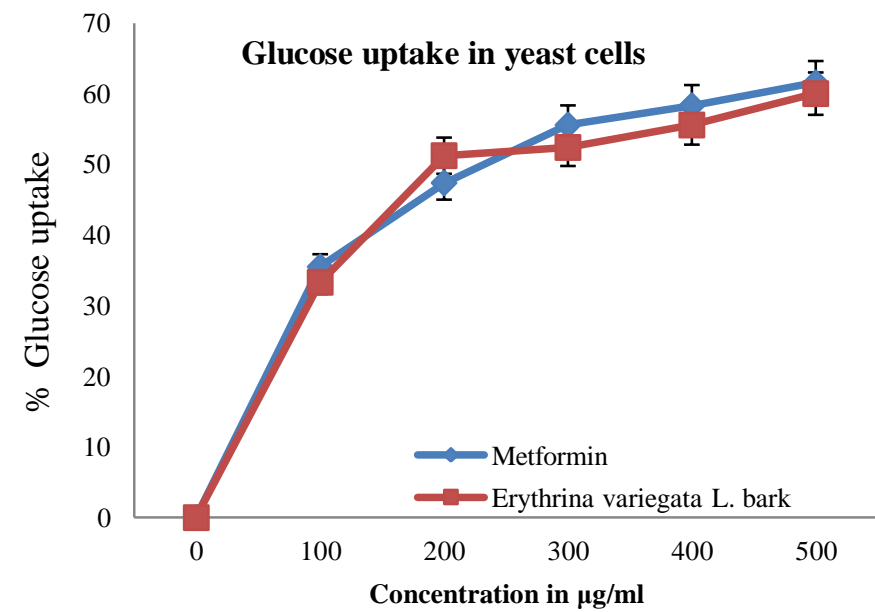

Fig. 4: Glucose uptake in Yeast cells assay of E. variegata L. bark extract. Values are expressed as Mean \pm SD of triplicates

Inhibitory assay of $\alpha$-amylase $\& \alpha$-glucosidase activity of methanolic bark extract of Erythrina variegata $\mathrm{L}$.

Among the different anti-diabetic therapeutic approaches one major strategy is dropping gastrointestinal absorption of glucose by inhibition of carbohydrate metabolizing enzymes alpha-amylase and alpha- glucosidase. Pancreatic and intestinal glucosidases are the key enzymes of dietary carbohydrate digestion and inhibitors of these enzymes may be effective in retarding glucose absorption. This is because only monosaccharides are readily taken up from the intestine and all other carbohydrates have to be broken-down enzymatically before they can be absorbed. In previous reports $M$. uniflorum leaves showed $\alpha$-amylase and $\alpha$-glucosidase inhibitory potential when compared with standard drug indicated that extreme inhibition of pancreatic - amylase could result in the irregular bacterial fermentation of undigested carbohydrates in the colon and therefore gentle -amylase inhibition action is desirable (Priyanga et al., 2015). The inhibitory action of methanolic bark extract of Erythrina variegata L. were increased as the concentration increases in both the extract and the standard acarbose and both the graphs were shown in Figure 5 and 6.

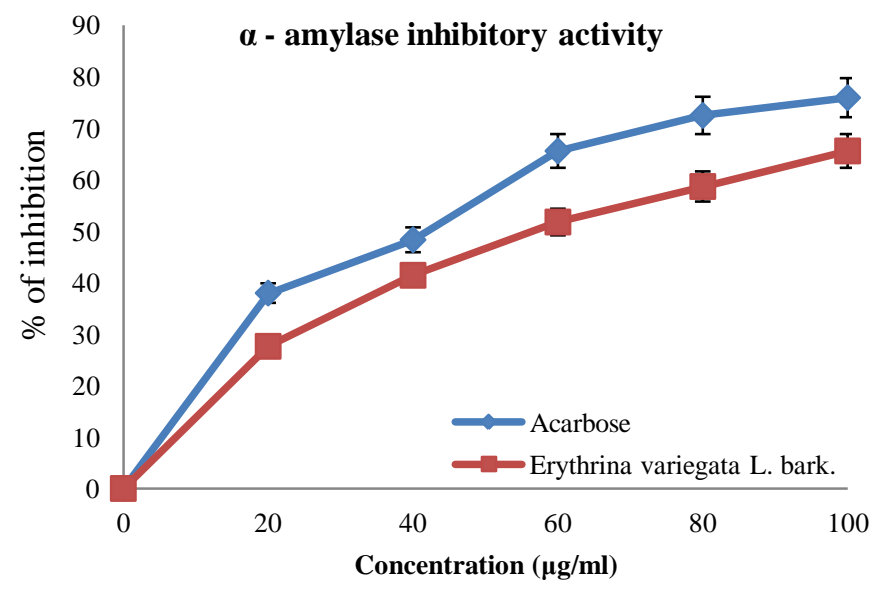

Fig. 5: $\alpha$ - amylase inhibitory activity of E. variegata L. bark extract. Values are expressed as Mean \pm SD of triplicate. 


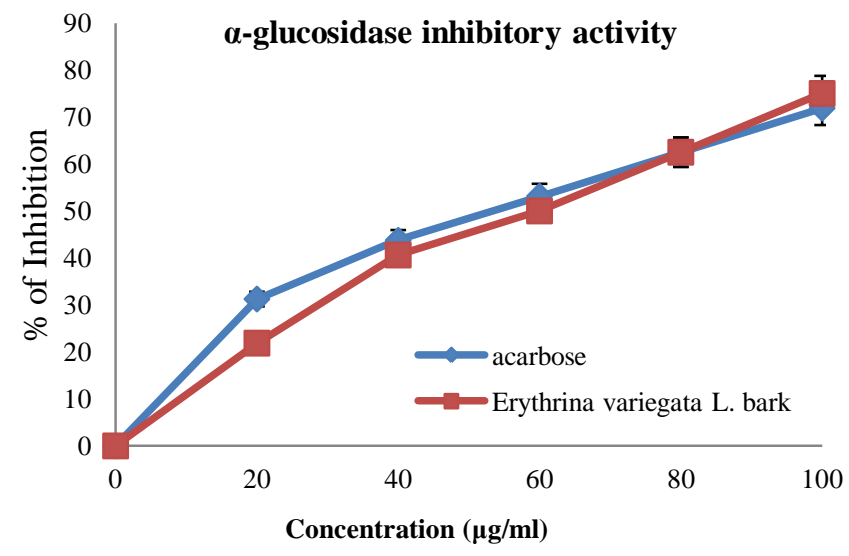

Fig. 6: $\alpha$-glucosidase inhibitory activity of $E$. variegata L. bark extract. Values are expressed as Mean \pm SD of triplicates

\section{Non-enzymatic glycosylation of hemoglobin}

The methanolic bark extract of Erythrina variegata L. shows an excellent inhibition of glycosylated hemoglobin. The percentage inhibition of glycosylation is dose dependent (Figure 7). The hemoglobin present in the red blood corpuscles has a tendency to get bound to glucose and form an HbA1c. The greater the blood-glucose concentration, the greater is the amount of glucose-bound (glycosylated) hemoglobin. Such glucose hemoglobin linkage is rather constant and lasts for 60 to 120 days (the life-span of red blood corpuscles). Thus the amount of glycosylated hemoglobin is a convinced steer to the concentration of glucose in the blood. Amount of glycated hemoglobin should not be more than $12 \%$ (Radhika et al., 2013). In case of standard drug the concentration of drug increases, the formation of glucosehemoglobin complex decreases and free hemoglobin increases and shows the inhibition of glycosylated hemoglobin.

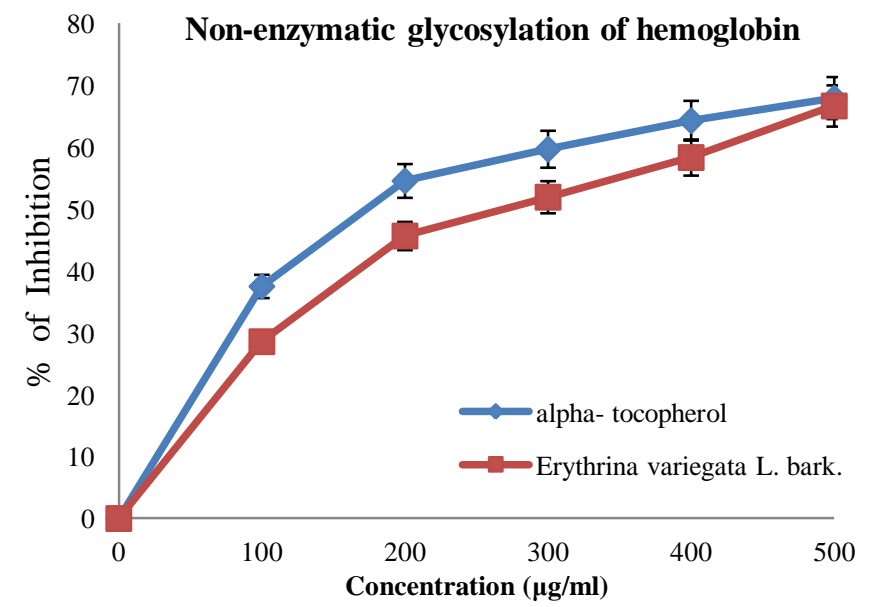

Fig. 7: Non-enzymatic glycosylation of hemoglobin of E. variegata L. bark extract.

Values are expressed as Mean \pm SD of triplicates

\section{Anti-inflammatory effect of methanolic extract of Erythrina variegata $\mathbf{L}$. bark \\ Chloroform and water extract of E.variegata Linn} showed significant stabilization towards HRBC (Human RBC) membrane. Inflammation is a common phenomenon and it is a reaction of living tissue. This can be done by using HRBC method. It clearly indicates that the inflammation shortened compared with the control. The anti-inflammatory property of Erythrina variegata was due to the presence of alkaloid or steroid in the crude extract (Reddy et al., 2015).

The membrane stabilization was increased as the concentration of the plant extract increases the $\mathrm{IC}_{50}$ value of plant extract and the standard was found to be $364.26 \pm 0.74 \mu \mathrm{g} / \mathrm{ml}$ and $340.66 \pm 0.95 \mu \mathrm{g} / \mathrm{ml}$ respectively.

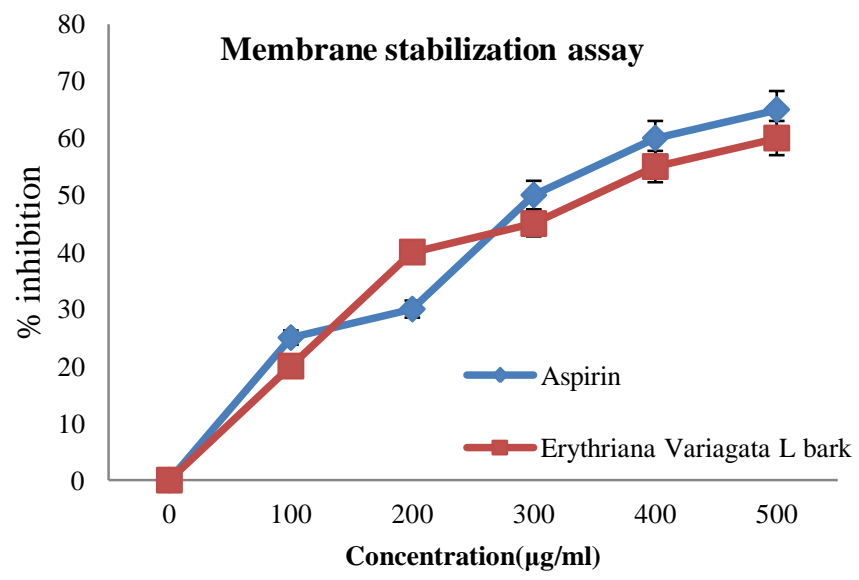

Figure 8: Membrane stabilization assay of $E$. variegata $L$. bark extract Values are expressed as Mean \pm SD of triplicates

\section{GC-MS spectral analysis of methanolic extract of Erythrina variegata $\mathbf{L}$. bark}

Gas chromatography-mass spectrometry (GC-MS) is a technique that combines the features of gas-liquid chromatography and mass spectrometry to recognize different substances within a test sample (Joseph et al., 2014).

The results pertaining to GC-MS analysis of the methanolic extract of E. variegata lead to the identification of a number of compounds. These compounds were identified through mass spectrometry attached with GC. The various compounds present in the entire herb of E. variegata detected by the GC-MS are shown in Table 3.

In the GC-MS analysis, 58 compounds were identified in the methanolic extract of Erythrina variegata L. bark and were mentioned in table below. The identification of compounds is based on the peak area, molecular weight and molecular formula.

These compounds are responsible for pharmacological activities. Out of 58 compounds, 3 compounds has highest peak area, they are Palmitic acid (17.44), Octadecadienoic acid (13.3) and Diacetyllycorine lactam (12.7).

Palmitic acid has the property of antioxidant and antimicrobial activities. It has the property of larvicidal effect. Octadecadienoic acid has the property of anti-inflammatory and anti-arthritic activity (Lalitharani et al., 2010). Diacetyl lycorine lactam is the most abundant alkaloid exhibits promising anticancer activity (Wang et al., 2014). 


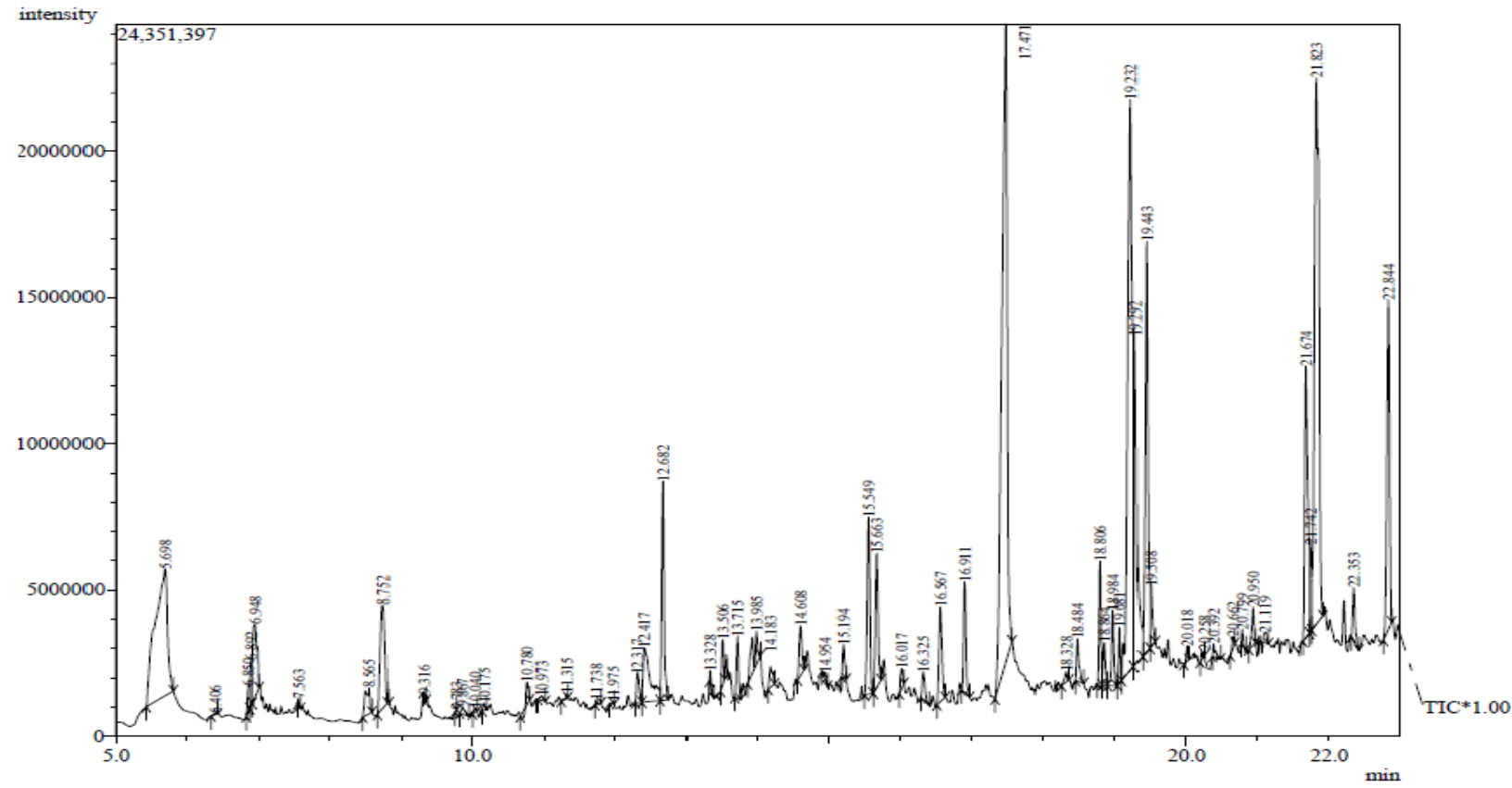

Fig. 9: GC-MS Chromatogram of methanolic extract of E. variegata L. bark extract.

Table 3: GC-MS spectral analysis of E. variegata L. bark extract.

\begin{tabular}{|c|c|c|c|c|c|}
\hline S. No & RT & Name of the compound & Molecular formula & Molecular weight & Peak area $\%$ \\
\hline 1. & 5.698 & 1-Butanol & $\mathrm{C}_{6} \mathrm{H}_{12} \mathrm{O}_{2}$ & 116 & 8.13 \\
\hline 2 & 6.406 & Acetamide & $\mathrm{C}_{5} \mathrm{H}_{8} \mathrm{~N}_{2} \mathrm{O}_{3}$ & 144 & 0.02 \\
\hline 3 & 6.850 & 7h-Pyrrolo[1,2-A]Azepine & $\mathrm{C}_{10} \mathrm{H}_{9} \mathrm{~N}$ & 143 & 0.33 \\
\hline 4 & 6.892 & 1H-Indole-3-Ethanol & $\mathrm{C}_{12} \mathrm{H}_{13} \mathrm{NO}_{2}$ & 203 & 0.33 \\
\hline 5 & 6.948 & 4-Ethynylbenzaldehyde & $\mathrm{C}_{9} \mathrm{H}_{6} \mathrm{O}$ & 130 & 1.61 \\
\hline 6 & 7.563 & 1h-Indene & $\mathrm{C}_{25} \mathrm{H}_{42}$ & 342 & 0.05 \\
\hline 7 & 8.565 & 1h-Indole & $\mathrm{C}_{8} \mathrm{H}_{7} \mathrm{~N}$ & 117 & 0.62 \\
\hline 8 & 8.752 & 2-Methoxy-4-Vinylphenol & $\mathrm{C}_{9} \mathrm{H}_{10} \mathrm{O}_{2}$ & 150 & 2.38 \\
\hline 9 & 9.316 & O-Ethyl O-N-Octyl Ethyl Phosphonate & $\mathrm{C}_{12} \mathrm{H}_{27} \mathrm{O}_{3} \mathrm{P}$ & 250 & -0.05 \\
\hline 10 & 9.783 & Dimethyl(Divinyl)Stannane & $\mathrm{C}_{6} \mathrm{H}_{12} \mathrm{Sn}$ & 204 & 0.00 \\
\hline 11 & 9.867 & 2H-Quinoline-1-Carboxylic Acid, & $\mathrm{C}_{11} \mathrm{H}_{13} \mathrm{NO}_{2}$ & 191 & 0.11 \\
\hline 12 & 10.040 & 1,5-Dihydroxy-1,2,3,4-Tetrahydronaphthalene & $\mathrm{C}_{10} \mathrm{H}_{12} \mathrm{O}_{2}$ & 164 & 0.05 \\
\hline 13 & 10.175 & Benzaldehyde & $\mathrm{C}_{8} \mathrm{H}_{8} \mathrm{O}_{3}$ & 152 & 0.08 \\
\hline 14 & 10.780 & 2-Allyl-6-Methoxyphenol & $\mathrm{C}_{10} \mathrm{H}_{12} \mathrm{O}_{2}$ & 164 & 0.19 \\
\hline 15 & 10.97 & Malonic Acid & $\mathrm{C}_{16} \mathrm{H}_{30} \mathrm{O}_{4}$ & 286 & 0.07 \\
\hline 16 & 11.315 & Thiourea & $\mathrm{C}_{19} \mathrm{H}_{21} \mathrm{~N}_{3} \mathrm{OS}$ & 339 & 0.04 \\
\hline 17 & 11.738 & 1,2-Benzenediol & $\mathrm{C}_{10} \mathrm{H}_{14} \mathrm{O}_{2}$ & 166 & 0.02 \\
\hline 18 & 11.975 & 1,2,4-Cyclopentanetrione & $\mathrm{C}_{10} \mathrm{H}_{12} \mathrm{O}_{3}$ & 180 & 0.01 \\
\hline 19 & 12.317 & Phenol & $\mathrm{C}_{11} \mathrm{H}_{16} \mathrm{O}_{2}$ & 180 & 0.44 \\
\hline 20 & 12.417 & Quinoline & $\mathrm{C}_{10} \mathrm{H}_{9} \mathrm{~N}$ & 143 & 2.02 \\
\hline 21 & 12.682 & Caryophyllene Oxide & $\mathrm{C}_{15} \mathrm{H}_{24} \mathrm{O}$ & 220 & 2.71 \\
\hline 22 & 13.328 & 1H-3a,7-Methanoazulene-6-Methanol & $\mathrm{C}_{15} \mathrm{H}_{24} \mathrm{O}$ & 220 & 0.03 \\
\hline 23 & 13.506 & Rosifoliol & $\mathrm{C}_{15} \mathrm{H}_{24} \mathrm{O}$ & 220 & 0.44 \\
\hline 24 & 13.715 & "Neoclovenoxid-Alkohol" & $\mathrm{C}_{15} \mathrm{H}_{24} \mathrm{O}$ & 220 & 0.70 \\
\hline 25 & 13.985 & Phenol, & $\mathrm{C}_{11} \mathrm{H}_{14} \mathrm{O}_{3}$ & 194 & 0.93 \\
\hline 26 & 14.183 & Benzoic Acid & $\mathrm{C}_{10} \mathrm{H}_{12} \mathrm{O}_{4}$ & 196 & 0.34 \\
\hline 27 & 14.60 & Tetradecanoic Acid & $\mathrm{C}_{14} \mathrm{H}_{28} \mathrm{O}_{2}$ & 228 & 0.70 \\
\hline 28 & 14.954 & 1-Cyclohexene-1-Methanol, & $\mathrm{C}_{11} \mathrm{H}_{20} \mathrm{O}$ & 168 & 0.04 \\
\hline 29 & 15.194 & Pluchidiol & $\mathrm{C}_{13} \mathrm{H}_{20} \mathrm{O}_{2}$ & 208 & 0.37 \\
\hline 30 & 15.549 & Epiglobulol & $\mathrm{C}_{15} \mathrm{H}_{26} \mathrm{O}$ & 222 & 2.48 \\
\hline 31 & 15.663 & 3,7,11,15-Tetramethyl-2-Hexadecen-1-Ol & $\mathrm{C}_{20} \mathrm{H}_{40} \mathrm{O}$ & 296 & 1.87 \\
\hline 32 & 16.017 & Pentadecanoic Acid & $\mathrm{C}_{15} \mathrm{H}_{30} \mathrm{O}_{2}$ & 242 & 0.24 \\
\hline 33 & 16.325 & 2-Methyl-7-Octadecyne & $\mathrm{C}_{19} \mathrm{H}_{36}$ & 264 & 0.37 \\
\hline 34 & 16.567 & 4,4,8-Trimethyltricyclo[6.3.1.0(1,5)]Dodecane-2,9-Diol & $\mathrm{C}_{15} \mathrm{H}_{26} \mathrm{O}_{2}$ & 238 & 1.47 \\
\hline 35 & 16.911 & Hexadecanoic Acid & $\mathrm{C}_{17} \mathrm{H}_{34} \mathrm{O}_{2}$ & 270 & 1.32 \\
\hline 36 & 17.471 & Palmitic Acid & $\mathrm{C}_{16} \mathrm{H}_{32} \mathrm{O}_{2}$ & 256 & 17.44 \\
\hline 37 & 18.328 & Methyl 2-Hydroxy-Hexadecanoate & $\mathrm{C}_{17} \mathrm{H}_{34} \mathrm{O}_{3}$ & 286 & 0.14 \\
\hline 38 & 18.484 & Heptadecanoic Acid & $\mathrm{C}_{17} \mathrm{H}_{34} \mathrm{O}_{2}$ & 270 & 0.54 \\
\hline 39 & 18.806 & Methyl 10-Trans,12-Cis-Octadecadienoate & $\mathrm{C}_{19} \mathrm{H}_{34} \mathrm{O}_{2}$ & 294 & 1.15 \\
\hline 40 & 18.864 & Linolenic Acid & $\mathrm{C}_{19} \mathrm{H}_{32} \mathrm{O}_{2}$ & 292 & 0.51 \\
\hline
\end{tabular}




\begin{tabular}{|c|c|c|c|c|c|}
\hline 41 & 18.984 & Phytol Isomer & $\mathrm{C}_{20} \mathrm{H}_{40} \mathrm{O}$ & 296 & 0.86 \\
\hline 42 & 19.081 & Methyl 16-Methyl-Heptadecanoate & $\mathrm{C}_{19} \mathrm{H}_{38} \mathrm{O}_{2}$ & 298 & 0.48 \\
\hline 43 & 19.232 & 9,12-Octadecadienoic Acid (Z,Z)- & $\mathrm{C}_{18} \mathrm{H}_{32} \mathrm{O}_{2}$ & 280 & 13.33 \\
\hline 44 & 19.292 & 1,Z-5,E-7-Dodecatriene & $\mathrm{C}_{12} \mathrm{H}_{20}$ & 164 & 4.39 \\
\hline 45 & 19.443 & Stearic Acid & $\mathrm{C}_{18} \mathrm{H}_{36} \mathrm{O}_{2}$ & 284 & 5.72 \\
\hline 46 & 19.508 & 9h-Fluorene-4,5-Dicarbaldehyde & $\mathrm{C}_{15} \mathrm{H}_{10} \mathrm{O}_{2}$ & 222 & 0.65 \\
\hline 47 & 20.018 & 1,7-Dimethyl-9,10-Phenanthrenedione & $\mathrm{C}_{16} \mathrm{H}_{12} \mathrm{O}_{2}$ & 236 & 0.11 \\
\hline 48 & 20.258 & 5-Bromovaleric Acid & $\mathrm{C}_{13} \mathrm{H}_{23} \mathrm{BrO}_{2}$ & 290 & 0.08 \\
\hline 49 & 20.392 & Carbonic Acid & $\mathrm{C}_{18} \mathrm{H}_{33} \mathrm{C}_{13} \mathrm{O}_{3}$ & 402 & 0.12 \\
\hline 50 & 20.662 & Methyl Icosanoate & $\mathrm{C}_{21} \mathrm{H}_{42} \mathrm{O}_{2}$ & 326 & 0.12 \\
\hline 51 & 20.799 & Octadecanoic Acid & $\mathrm{C}_{19} \mathrm{H}_{38} \mathrm{O}_{4}$ & 330 & 0.08 \\
\hline 52 & 20.950 & Eicosanoic Acid & $\mathrm{C}_{20} \mathrm{H}_{40} \mathrm{O}_{2}$ & 312 & 0.46 \\
\hline 53 & 21.119 & 1-Acetyl-2,2,4-Trimethyl-4-Phenyl-1,2,3,4-Tetrahydroquinoline & $\mathrm{C}_{20} \mathrm{H}_{23} \mathrm{NO}$ & 293 & 0.13 \\
\hline 54 & 21.674 & 6,7,8-Trimethoxy-3,4-Dimethyl-1-Methylsulfanyl-3,4-Dihydroisoquinoline & $\mathrm{C}_{15} \mathrm{H}_{21} \mathrm{NO}_{3} \mathrm{~S}$ & 295 & 4.37 \\
\hline 55 & 21.742 & Isoquinoline & $\mathrm{C}_{18} \mathrm{H}_{18} \mathrm{~N}_{2} \mathrm{O}_{4}$ & 326 & 0.76 \\
\hline 56 & 21.823 & DiacetylLycorine Lactam & $\mathrm{C}_{20} \mathrm{H}_{19} \mathrm{NO}_{7}$ & 385 & 12.74 \\
\hline 57 & 22.353 & Erythrinan-16-Ol & $\mathrm{C}_{18} \mathrm{H}_{21} \mathrm{NO}_{3}$ & 299 & 6.63 \\
\hline 58 & 22.844 & 2-Amino-5-Isopropyl-6,7-Dimethoxy-1,3-Azulenedicarbonitrile & $\mathrm{C}_{17} \mathrm{H}_{17} \mathrm{~N}_{3} \mathrm{O}_{2}$ & 295 & 4.58 \\
\hline
\end{tabular}

\section{CONCLUSION}

By considering the above data it can be concluded that the bark of Erythrina variegata L has medicinal values since it contains more secondary metabolites and its free radical scavenging activity were found to have considerable antioxidant potential. This plant also reveal better in vitro enzyme inhibitory activity (alpha amylase and alpha glucosidase) which are involved in regulation and absorption of carbohydrate, inhibition of nonenzymatic glycosylation of hemoglobin, anti-diabetic activity proved by glucose uptake assay and also exhibits good antiinflammatory activity. The present data, illustrate that the methanolic extract of Erythrina variegata L. bark has good medicinal properties and it will be useful in treating various diseases including diabetes.

\section{ACKNOWLEDGEMENT}

We, the authors are thankful to Chancellor, Chief Executive Officer, Vice Chancellor and Registrar of Karpagam University for providing facilities and encouragement.

\section{CONFLICT OF INTEREST}

We declare that we have no conflict of interest.

\section{REFERENCES}

Apostolidis E, Kwon YI, Shetty K. Inhibitory potential of herb, fruit, and fungal - enriched cheese against key enzymes linked to type 2 diabetes and hypertension. Innov Food Sci Emerg Technol, 2007; 8:46-54

Baskar N, Devi PB, Kumar MR. Anti cancer activity of methanol extract of root bark of Erythrina variegata Linn. Int J Toxicol Pharm Res, 2010; 2:74-76.

Blois MS. Antioxidant determinations by the use of stable free radical. Nature, 1958; 81:1199-2000.

Chandra S, Chatterjee P, Dey P, Bhattacharya S. Evaluation of in vitro anti-inflammatory activity of coffee against the denaturation of protein. Asian Pac J Trop Med, 2012; 178-180.

Chew YL, Chan EWL, Tan PL, Lim YY, Stanslas J and Goh JK. Assessment of phytochemical content, polyphenolic composition, antioxidant and antibacterial activities of Leguminase medicinal plants in Peninsular. BMC complementary Altern Med, 2011; 11-12.
Daksha G, Chandrashekher KS, Pal G. In vitro antidiabetic activity of Pentacyclic tritrprnoida and fatty acid ester from Bauhinia purpurea. Int J Pharm Pharm Tech, 2013; 2:25-28.

Devaki K, Hemmalakshmi S, Priyanga S. HPTLC analysis and in vitro antioxidant activity of aqueous bark extract of Erythrina variegata L. Isr J Plant Sci, 2015; doi.org/10.1080/07929978.2015.1096608.

Devi RM, Manoharan A. Characteristics of pharmacognostical significance of Erythrina variegata Var. and Ficus racemosa Linn. bark. J Chem Pharm Res, 2011; 3:707-714.

Dinesh Kumar A, Mitra M, Manjunatha. In vitro and in vivo studies of antidiabetic Indian medicinal plants: A Review. J Herb Med Toxicol, 2009; 3:9-14.

Harborne JB. Phytochemical Methods 1st edn, London, Chapman and Hall, 1973, 288-504.

Joseph AP, Hemmalakshmi S, Priyanga S, Devaki K. Phytochemical screening, GC-MS analysis and enzyme inhibitory activity of Passiflora foetida L. Indo Am J of Pharm Res, 2014; 4:3526-3534.

Jyothi KSN, Hemalatha P, Calla S. Evaluation of alpha amylase inhibitory potential of three medicinally important traditional wild food plants of India. Int J Green Pharm, 2011; 95-99.

Kumar A, Lingadurai S, Jain A, Barman NR. Erythrina variegata Linn: A Review on morphology, phytochemistry, and pharmacological aspects. Pharmacogn Rev, 2010; 4:147-152.

Lalitharani S, Ramasamy V, Mohan and Regini GS. GC-MS analysis of ethanolic extract of Zanthoxy lumrhetsa (roxb.) DC spines. J Herb Med Toxicol, 2010; 4:191-192.

Mc Cue P, Vattern D, Shetty K. Inhibitory effect of Clonal oregano extracts against porcine pancreatic amylase in vitro. Asia Pac $\mathrm{J}$ Clin Nutr, 2004; 13:401-408.

Megha G, Chaudhari ,Bhoomi B, Joshi, Kinnari N. Mistry, Brijesh Dabhi and Lal S. In vitro antimicrobial activity of stem bark of Bauhinia purpurea. Int Sci Press, 2013; (India),4:29-35.

Megha G, Chaudhari, Bhoomi B, Joshi, Kinnari N, Mistry. In vitro anti diabetic and anti-inflammatory activity of stem bark of Bauhinia purpurea. Bull Pharm Med Sci, 2013; 1:139-150.

Ordon LE, Gomez JD, Vattuone MA and Isla MI. Antioxidant activities of Sechium edule (Jacq.) swart extracts. Food Chem, 2006; 97:452-458.

Oyaizu M. Studies on product of browning reaction prepared from glucose amine. Japan J Nut, 1986; 7:307-315.

Patel DK, Prasad SK, Kumar R, Hemalatha S. An overview on antidiabetic medicinal plants having insulin mimetic property. Asian Pac J Trop Med, 2012; 320-33.

Priyanga S, Hemmalakshmi S, Devaki K. Comparative chromatographic fingerprint profiles of ethanolic extract of Macrotyloma uniflorum L. leaves and stem. Int J Pharm Cli Res, 2014; 6:288-299.

Priyanga S, Hemmalakshmi S, Devaki K. Comparative phytochemical investigation of leaf, stem, flower and seed 
extracts of Macrotyloma uniflorum L. Indo Am J Pharm Res, 2014; 4:5415-5420.

Priyanga S, Hemmalakshmi S, Sowmya S, Vidya B, Chella Perumal P, Gopalakrishnan VK, Devaki K. In vitro enzyme inhibitory evaluation and free radical scavenging potential of ethanolic leaf extract of Macrotyloma uniflorum (L.). Int J of Cur Pharm Rev and Res, 2015; 6:169-177.

Priyanga S., Hemmalakshmi S., Sowmya S., Vidya B., ChellaPerumal P., Gopalakrishnan V. K. And Devaki K. Quantitative evaluation and in vitro free radical scavenging ability of ethanolic stem extract of Macrotyloma uniflorum L. Der Pharmacia Lettre, 2016; 7:225233.

Radhika S, Senthil Kumar R, Sindhu S, Sagadevan E, Arumugam P. Phytochemical investigation and evaluation of antihyperglycemic potential of Premna corymbosa. Int J Pharm PharmSci, 2013; 5:352-356.

Reddy NVLS, Anarthe SJ, Raghavendra NM. Effect of thermal treatment an phenolic content. J Res Biomed Sci, 2010; 1:72-75.

Reddy SK, Krishna Naik K, Karthikeyan R. Anti-inflammatory activity of the leaf extracts of Erythrina variegata L. Inventi Rapid: Ethnopharmacology, 2015; 1:1-2.

Sangeetha MS, Priyanga S, Hemmalakshmi S, Devaki K. In vivo antidiabetic potential of Cyclea peltata in streptozotocin-induceddiabetic rats. Asian J Pharm Cli Res, 2015; 8:103-108.

Sangita C, Priyanka C, Protapaditya D, Sanjib B.Evaluation of in vitro anti-inflammatory activity of coffee against the denaturation of protein. Asian Pac J Trop Biomed, 2012; S178-S180.

Scharff T. Evidence for hexose transport in acetone-dried yeast. Arch Biochem Biophys, 1961; 95:329-335.

Sindhu S, Kavrekar V, Mishra A. In vitro studies on alpha amylase and alpha glucosidase inhibitory activities of selected plant extracts. Euro J Exp Bio, 2013; 3:128-132.

Singleton VL, Rossi JA. Colorimetry of total phenolics with phosphomolybdic phospho tugnstic acid reagents. Am J Enol Vitic, 1965; $16: 144-158$
Sowmya S, Chella Perumal P, Anusooriya P, Vidya B, Pratibha $\mathrm{P}$, Gopalakrishnan, V. K. In vitro antioxidant activity, in vivo skin irritation studies and HPTLC analysis of Cayratia trifolia (L.) Domin. Int J Toxicol Pharm Res, 2015; 7:1-9.

Trease GE, Evans WC (1996). Pharmacognosy 4th Edition, W B Saunders, USA: 243-283.Hh.

Upwar N, Patel R, Waseem N, Mahobia NK. Hypoglycemic effect of methanolic extract of Berberis aristata DC stem on normal and streptozotocin induced diabetic rats. Int J Pharm Pharm Sci, 2011; 3:222224.

Vijayameena C, Subhashini G, Loganayagi M, Ramesh B. Phytochemical screening and assessment of antibacterial activity for the bioactive compounds in Annona muricata. Int J Curr Microbiol App Sci, 2013;2:1-8.

Wagner H, Bladt S. 2004. Plant Drug Analysis-A Thin Layer Chromatography Atlas. 2nd Ed, New Delhi, Thompson Press Ltd.

Wang P, Yuan H, Zhang X, Li Y, Shang L, Yin Z. Novel lycorine derivatives as anticancer agents: synthesis and in vitro biological evaluation. Molecules, 2014; 19:2469-2480.

West IC. Radicals and oxidative stress in diabetes. Diabet Med, 2000; 17:171-180.

\section{How to cite this article:}

Santhiya N, Priyanga S, Hemmalakshmi S, Devaki K. Phytochemical analysis, Anti inflammatory activity, In vitro antidiabetic activity and GC-MS profile of Erythrina variegata L. bark. J App Pharm Sci, 2016; 6 (07): 147-155. 